\title{
PERCEPTION OF THE NURSING TEAM ABOUT THE ROLE OF HOSPITAL NURSING MANAGER
}

\author{
Percepção da equipe de enfermagem sobre a função do gerente de \\ enfermagem hospitalar
}

\section{Percepción del equipo de enfermería sobre el papel gestor de enfermería en el hospital}

Natalia Maria Freitas e Silva Maia ${ }^{1}$,Brenda Amélia Valcacer Fonseca², Erika Wanessa Oliveira Furtado Andrade ${ }^{3}$, José Arnaldo Moreira de Carvalho Jr. ${ }^{4}$, Lennara de Siqueira Coelho ${ }^{5}$, Sayonnara Ferreira Maia ${ }^{6}$

\section{How to cite this article:}

Maia NMFS, Fonseca BAV, Andrade EWOF, Carvalho JAM, Coelho LS, Maia SF. Perception of the nursing team about the role of hospital nursing manager. Rev Fun Care Online. 2020 jan/dez; 12:1-5. DOI: http://dx.doi.org/ 10.9789/2175-5361.rpcfo.v12.6555.

\begin{abstract}
Objective: to analyze the perception of the nursing team about the role of the hospital nursing manager, and how this interferes with the quality of care provided by the team. Methods: descriptive and exploratory research, qualitative approach of the data, performed with 20 Nursing professionals. For the analysis of the results, the Collective Subject Discourse method was used. Results: collective thinking was grouped in 04 classes: The bureaucratic function associated with management and the manager-nursing team relations; Skills perceived by the nursing team for the work of the Nursing manager; Challenges in the nursing manager's role perceived by the nursing team; The influence of the nursing manager on the quality and the assistance provided to the client. Conclusion: the activity of the nursing manager is extremely bureaucratic, and seen by the Nursing team as hierarchical, contributing to distance the manager from the conviviality with the team. Descriptors: Nursing; Nursing team; Hospital administration.
\end{abstract}

\section{RESUMO}

Objetivo: analisar a percepção da equipe de enfermagem sobre a função do gerente de enfermagem hospitalar, e como essa interfere na qualidade da assistência prestada pela equipe. Método: pesquisa descritiva e exploratória, de abordagem qualitativa dos dados, realizado com 20 profissionais de Enfermagem. Para análise dos resultados, utilizou-se o método do Discurso do Sujeito Coletivo. Resultados: o pensamento coletivo foi agrupado em 04 classes: A função burocrática associada a gerência e as relações gerente-equipe de enfermagem;

1 Nursing Graduate, MSc in Nursing by the UFPI, Coordinator of the Nursing Graduation Course at Faculdade do Piaui (FAPI), Professor at AESPI.

2 No information available.

3 Nursing Graduate, MSc in Nursing by the UFPI.

4 Nursing Graduate, MSc in Nursing by the UFPI, Professor at FAPI, Professor at AESPI.

5 Nursing Graduate, MSc in Nursing by the Centro Universitário Uninovafapi (Uninovafapi), Professor at FAPI, Coordinator of the Nursing Graduation Course at AESPI.

6 Nursing Graduate, MSc in Nursing by the UFPI, Professor at AESPI. 
Competências percebidas pela equipe de enfermagem para o trabalho do gerente de Enfermagem; Desafios na função do gerente de enfermagem percebidos pela equipe de enfermagem; A influência do gerente de enfermagem na qualidade e na assistência prestada ao cliente. Conclusão: a atividade do gerente de enfermagem é extremamente burocrática, e vista pela equipe de Enfermagem como hierarquizada, contribuindo para distanciar o gerente do convívio com a equipe.

Descritores: Enfermagem; Equipe de enfermagem; Administração hospitalar.

\section{RESUMÉN}

Objetivo: analizar la percepción del equipo de enfermería sobre el papel de gestor de enfermería en el hospital, y cómo esto afecta a la calidad de la atención prestada por el personal. Métodos: estudio descriptivo y exploratorio de abordaje cualitativo, realizado con 20 profesionales de enfermería. Para el análisis de los datos, se utilizó el método del Discurso del Sujeto Colectivo. Resultados: el pensamiento de grupo se agrupan en 04 clases: la función burocrática asociada con la administración y gestión de relaciones con el personal de enfermería; Habilidades percibidas por el equipo de enfermería para el trabajo del administrador de enfermería; Desafíos en la función del gestor de enfermería percibida por el personal de enfermería; La influencia del gerente de enfermería en la calidad y servicio prestado al cliente. Conclusión: la actividad del administrador de enfermería es muy burocrático y visto por el personal de enfermería como jerárquica, ayudando a distanciar al gestor de interacción con el personal. Descriptores: Enfermería; Grupo de enfermería; Administración hospitalaria.

\section{INTRODUCTION}

The National Curricular Guidelines for Nursing Graduation Courses underline that among having different skills and abilities, the nurses also must be able to take initiatives, manage and administer the workforce and physical, material and information resources, in addition to being entrepreneurs, managers, employers or leaders in the health team. ${ }^{1}$ It is because the nursing practice requires from the registered nurse theoretical and practical knowledge, in order to enable him to develop different skills and abilities, in the care, management, educational and research field. ${ }^{2}$

The registered nurse is usually the professional responsible for assuming the managerial activity, and he is responsible for the coordination of the nursing team, as well as the feasibility of the care process. ${ }^{3}$

The competencies for the position exceed the specific definitions of "manageability" because it involves differentiated strategies that add values to the organizations. The nurse manager must continually develop, seeking to acquire new skills necessary for his professional practice, valuing and improving the already developed individual skills, based on the needs highlighted in the workplace context. ${ }^{4}$

Although the managerial function is exclusive to the registered nurse, as provided by the Regulation of the Professional Exercise of Nursing, it is a consensus among specialists that this is not an isolated function and should be seen with "hierarchical tones". The participation of the entire nursing team in the management process is important and relevant in the construction of nursing managerial work, based on the construction of a competency profile, an inherent function of this work. ${ }^{5}$
Participatory management is engaging and non-hierarchical. Nonetheless, aiming the aforesaid, it is necessary for the whole team to understand the importance of the managerial function for the improvement of management quality.

Based on these concepts and seeking to understand the nursing team viewpoint concerning the managerial function, the nursing team perception regarding the hospital nurse's managerial function was defined as the object of this research.

The study's goal was to analyze the nursing team viewpoint regarding the hospital nursing manager role, and how this may interfere with the quality of care provided by the nursing team.

\section{METHODS}

It is a descriptive-exploratory research with a qualitative approach, which was carried out with 20 Nursing Professionals working in a public hospital located in the Northeast region of Brazil. The hospital is considered of medium complexity and holds procedures as general, orthopedic, gynecological, urological and minor surgeries.

The sample was defined for convenience. To participate in the study, professionals should meet the following inclusion criteria: professional working time in the institution of at least one year, and not previously developed the role of hospital manager. Professionals on medical leave or vacation and those who refused the invitation were excluded.

Data were collected between September and October 2016, in a reserved room of the institution where the professional worked, guided by a semi-structured script, with questions about the sociodemographic data and about the nursing manager role according to the viewpoint of nursing professionals. Each interview was recorded and had an average duration of 25 minutes, later transcribed. For the analysis of the results, the Collective Subject Discourse (CSD) method was used. ${ }^{6}$

The main characteristic of the CSD is the organization of verbal empirical data obtained in the statements, which is then grouped by collective thinking into categories that are originated from the key expressions taken from the interviewees' discourses. ${ }^{7}$

In order to initiate this research, the authorization of the aforementioned hospital was requested aiming to have free access within the unit to the information of the participants and also to carry out the research. Subsequently, the project was sent to the Research Ethics Committee and obtained approval under the Certificado de Apresentação para Apreciação Ética (CAAE) [Certificate of Presentation for Ethical Appreciation] No. 55480916.8.0000.5512.

\section{RESULTS AND DISCUSSION}

Considering the participants, 14 were nurse technicians and 08 registered nurses. Prevalence of female gender (17), within the age group from 20 to 55 years old, and years of experience between 01 and 18 years (15). After the interviews, analysis of the statements and quantification of key expressions, the collective thinking was grouped into classes, specifically: 


\section{Class 1- The bureaucratic function associated with hospital administration and the manager- nursing team relationship}

Participants attribute management to a bureaucratic connotation, isolation and decision making. They still consider that the bureaucracy required by the managerial position interferes in the manager-nursing team relationship by driving away the nurse manager from the nursing team conviviality.

The nurse manager has to accompany the team in loco, so the team feels security in the assignments, seeing the difficulties and showing solutions to the problems. (deponent 07)

The manager is focused only on the bureaucratic function, which is another of his duties and forgets or does not have time to fulfill the other duties, leaving the team and the work vulnerable. (deponent 08 )

Because the manager stays a long time with the bureaucracy, he forgets a little bit about the reality experienced in the assistance service. (deponent 16)

Another aspect perceived was the absence of the manager in all the shifts (testimonials give particular emphasis in the night) and how the use of bureaucratic measures and of indirect communication interfere in the manager-team relationship, mainly by use of informative. The lack of this team-manager nursing contact saddens the night service staff. They also reinforce the use of informational bureaucracy as interference factors in the relationship.

For lack of direct information, proposed by the head, because the service is nocturnal. (deponent 04)

For us who work at night, we are isolated, the manager does not show up to know how the work is going on, if something is missing, and we get to know about the news by a third party or information wall. (deponent 09)

By the time he stays in the institution solving bureaucratic issues, this makes it very difficult for him to get access to night shift workers. (deponent 11)

Participants believe that the bureaucracy inherent in the position of the nursing manager is authoritarian and used to enforce rules. They do not perceive the contribution of the administrative position, the benefits to the organization of the nursing team work and to the quality of care services.

Each manager has diverse ways of imposing rules within his or her nursing team. (deponent 03)
By the very occupation of the management post and by the authority that management confers on him. (deponent 12)

Because it requires that the manager must be rigorous, that he must be impartial and often inflexible, generating discontent in the team professionals. (deponent 13)

\section{Class 2 - The skills perceived by the nursing team towards the nursing manager attributions}

When asked about which managerial skills were indispensable to the nursing manager, the participants listed a series of them, with emphasis on leadership, communication, interpersonal relationships, conflict management, decision making, and teamwork.

I believe leadership is indispensable. (deponent 12)

Being a leader and not a boss. (deponent 14)

Maintaining a dialogue with the team. (deponent 19)

Communicating about changes and routines [...]. (deponent 05)

Leadership was highlighted as a sine qua non condition for the management work process by the nurse to achieve the objectives in all undertaken activities. Moreover, the ability to influence the nursing team was related to good leadership. Furthermore, the nursing manager as the leading role in creating an empowering work environment.

\section{Class 3 - The challenges of the nursing manager perceived by the nursing team}

When they were questioned about what challenges were perceived by the participants in the role of the hospital nursing manager, different competencies were observed, usually being reasons for difficulties for the managerial work process.

[...] taking a leading role with your team. (deponent 10)

I believe that having a leadership role is a challenge because of the difficulty of working with people, where each one has a different opinion, because everyone cannot be liked. (deponent 16)

[...] being a leader capable of managing his team. (deponent 18) 
Another competence stressed by the subjects as a challenge of the managerial function is the interpersonal relationship, once the nursing team is generating conflicts.

I believe that dealing with people is very complicated, with different thoughts and attitudes. (deponent 02)

Dealing with team members, as each has an opinion. (deponent 15)

One of the biggest challenges of the nursing manager is managing conflicts. (deponent 17)

\section{Managing conflicts within the team. (deponent 20)}

It was observed as one of the limiting factors of the nursing manager the difficulty in maintaining autonomy, observed by the dependence and lack of freedom in the decisions and the resolutions of problems. Autonomy is allowed as necessary, in daily activities and in the managerial work process.

Another challenge pointed out by the team is the difficulty that the manager has in designing personnel for the accomplishment of scales with an insufficient number of employees, relocation due to absenteeism, among other factors that hamper the development of the work and the final result that is the quality of the care provided to a client.

\section{Class 4 - The nursing manager influence on both quality and assistance provided to a client}

In order to know how the actions of the nursing manager can influence the quality of care provided to a client, it was observed the linkage made by the participants of the existence of deficiencies in the institution. The nursing team argues that the provision of material resources is the managerial role of the nurse and indispensable for nursing work.

It can influence positively because the team is the mirror of your manager. It is important for the manager to motivate his employees because the demotivation is very bad for the team. When the team and the manager are nicely engaged, the work goes better. (deponent 17)

Solving all problems, without missing machines, equipment and other materials needed for work. (deponent 06)

Keeping all equipment at the station and maintaining them whenever they break. (deponent 07)

The activity of the nursing manager requires a lot of this professional. Such professional, aiming be able to develop such activity with excellence, has began to perform activities of bureaucratic administrative nature on a larger scale than those related to the nursing team and the care service.
This issue is a work loss for the Nursing Profession and can further overload the nursing team, impacting their perception regarding the position/function, also having a strong effect on the care quality.

Nursing managers need to deepen their knowledge about the organizational universe, its intricacies, the relationship with internal and external agents, values that reflect in the vision and institutional mission, in order to make the function that they perform a profession. It is necessary to disclose the nurse managers' activities so that the team feels coparticipant of the processes and can sustain the performance of the manager. ${ }^{8}$

According to the National Curricular Guidelines for Nursing Graduation Courses, among the different competencies and abilities, nurses must be able to take initiatives, manage and administer the workforce and physical, material and information resources, besides being entrepreneurs, managers, employers or leaders in the health team. ${ }^{1}$

Leadership is one of the essential conditions for the exercise of the nurses' work process, in order to achieve the goals in all activities performed. The nurse as a manager needs to acquire influence over the nursing team, exercising leadership that translates all managerial competencies. ${ }^{4}$

It is emphasized that the nursing manager as a leader is a key element of team dynamics, having a preponderant role in creating work environments, through the interaction and relationship they establish with each team member and with patients, establishing a key role in ensuring the quality of care. $^{9}$

Communication is the basis for any relationship since it is a means we use to contribute to the preservation and restoration of health and to satisfy the needs of internal and external clients in all fields where the nurse can act. ${ }^{4}$

It occurs from the interactions established by the nurse when performing the managerial functions in the context of nursing work, in other words, the human care, and the hospital as an indivisible. ${ }^{10}$

The decision-making process in the nurse manager's daily life is important to solve problems and solve conflicts, ensuring the harmony of the team. The manager needs to have knowledge, skills, and attitudes, in order to enable interaction with reality, to plan strategies and actions necessary to achieve the established objectives, using autonomy and impartiality in the decision-making process. ${ }^{4}$

The process of leadership is a challenge for the manager because it is an essential condition, which allows the visualization of a future with new perspectives and proposals for action, which can contribute to greater visibility and appreciation of the profession. ${ }^{11}$

It is considered necessary for managers to identify qualifying elements of hospital care, such as the care systematization, the valorization of teamwork and the satisfaction of all actors involved in care, since the continuous improvement of care quality should be considered by the nursing team as a dynamic process of identifying the indispensable factors in the work process of the nursing team. ${ }^{12}$ 


\section{CONCLUSIONS}

The activity of the nurse manager is extremely bureaucratic, and seen by the Nursing team as hierarchical, contributing to distance the manager from the conviviality with the team. The professionals recognize that the job requires a lot from those who work in such position, mainly knowledge and skills related not only to clinical practice but also to contextually dependent activities such as teamwork, conflict resolution among others.

The manager's greater dedication to bureaucratic activities has been seen by the team as a work loss for the Nursing Profession and can further overload the nursing team, impacting their perception regarding the position/function, also having a strong effect on the care quality.

\section{REFERENCES}

1. Brasil. Conselho Nacional de Educação (CNE). Resolução CNE/CES 3/2001. Dispõe sobre as Diretrizes Curriculares Nacionais do Curso de Graduação em Enfermagem. Diário Oficial da União, Brasília (DF);2001 Nov 9; Seção 1:37.

2. Felli VEA, Peduzzi M. O trabalho gerencial em enfermagem. In: Kurcgant P. Gerenciamento em enfermagem. 2. ed. Rio de Janeiro: Guanabara Koogan; 2010. p. 1-12.

3. Massaro M, Chaves LDP. A produção científica sobre gerenciamento em enfermagem hospitalar: uma pesquisa bibliográfica. Cogitare enferm. 2009;14(1):150-8. https://doi.org/10.5380/ce.v14i1.14135

4. Balsanelli AP, Feldman LB, Ruthes RM, Cunha ICKO. Competências Gerências: Desafio para o enfermeiro. 2. ed. São Paulo: Martinari, 2011.

5. Manenti SA, Ciampone MHT, Mira VL, Minami LF, Soares JMS $\mathrm{O}$ processo de construção do perfil de competências gerenciais para enfermeiros coordenadores de área hospitalar. Rev esc enferm USP. 2012;46(3):727-33. https://doi.org/10.1590/S008062342012000300027

6. Lefevre F, Lefevre AMC, Teixeira JJV. O Discurso do Sujeito Coletivo. Uma nova abordagem metodológica em pesquisa qualitativa. Caxias do Sul: Educs, 2000.

7. Nery IS, Feitosa JJM, Sousa ÁFL, Fernandes ACN. Abordagem da sexualidade no diálogo entre pais e adolescentes. Acta paul enferm. 2015;28(3):287-92. https://doi.org/10.1590/1982-0194201500048

8. Guerra ST, Prochnow AG, Trevizan MA, Azevedo GL. O conflito no exercício gerencial do enfermeiro no âmbito hospitalar. Rev LatinoAm Enfermagem. 2011;19(2):362-9. https://doi.org/10.1590/S010411692011000200019

9. Nunes E, Gaspar F. A liderança em enfermagem e a satisfação dos pacientes em contexto hospitalar. Rev Gaúcha Enferm. 2016;37(2):e55726 https://doi.org/10.1590/1983-1447.2016.02.55726

10. Santos JLG, Prochnow AG, Lima SBS, Leite JL, Erdmann AL. Concepções de comunicação na gerência de Enfermagem Hospitalar entre enfermeiros gerentes de um hospital universitário. Rev esc enferm USP. 2011;45(4):959-65. https://doi.org/10.1590/S008062342011000400024

11. Amestoy SC, Backes VMS, Thofehrn MB, Martini JG, Meirelles BHS, Trindade LL. Gerenciamento de conflitos: desafios vivenciados pelos enfermeiros-líderes no ambiente hospitalar. Rev Gaúcha Enferm. 2014;35(2):79-85. https://doi.org/10.1590/1983-1447.2014.02.40155

12. Gabriel CS, Gabriel AB, Bernardes A, Rocha FLR, Miasso AI Qualidade na assistência de enfermagem hospitalar: visão de alunos de graduação. Rev Gaúcha Enferm. 2010;31(3):529-35. https://doi. org/10.1590/S1983-14472010000300017

Received in: 12/06/2017

Required revisions: Did not have

Approved in: 12/07/2017

Published in: 10/01/2020

Corresponding author

Natália Maria Freitas e Silva Maia

Address: Rua/Av. Antônia Medeiros de Noronha, 3420

Bairro Socopo, Piauí, Brazil

Zip code: $64.063-040$

E-mail: nataliamfsmaia@gmail.com

Telephone number: +55 (86) 3232-2500 